\title{
Polymers and its applications in agriculture
}

\author{
Priscila Milani'1 , Débora França ${ }^{1}$, Aline Gambaro Balieiro ${ }^{1}$ and Roselena Faez ${ }^{1 *}$ \\ ${ }^{1}$ Laboratory of Polymer and Biosorbent Materials, Master in Agriculture and Environment Program, \\ Universidade Federal de São Carlos - UFSCar, Araras, SP, Brazil \\ *faez@cca.ufscar.br \\ Graphical Abstract
}

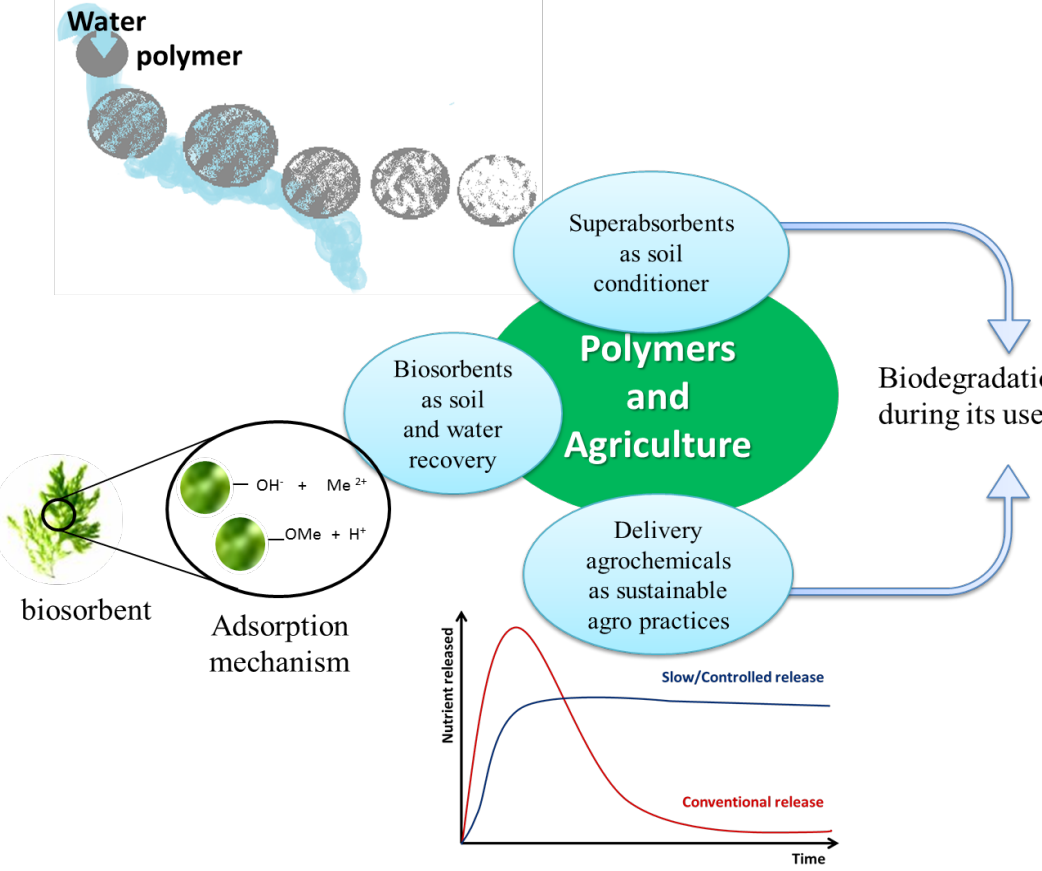

\begin{abstract}
Polymers are a class of soft materials with numerous and versatile mechanical and chemical properties that can be tuned specific to their application. Agriculture is an expanding area due to the requirement for indispensable food to meet the demands of a growing global population. Consequently, development of technology to improve the quality of the soil and agriculture manages is still under development. Intelligent agricultural supplies (controlled or slow release agrochemicals and superabsorbents) and biosorbents contribute to an expanding niche using technology from polymers. This review elucidates the state-of-the-art and will discuss some important aspects of using polymers in intelligent fertilizers, as well as superabsorbent, biosorbent and biodegradation processes in agriculture that are environmentally, technically, socially, and economically sustainable.
\end{abstract}

Keywords: controlled delivery system, biosorption, superabsorbent, biodegradation.

\section{Introduction}

The main growing, harvesting, and processing practices in agriculture were markedly achieved through the exploitation of natural resources, such as water and soil, combined with the excessive use of agrochemicals ${ }^{[1,2]}$. The high demand for fresh water, increasing manufacturing costs of agrochemicals as well as heightened awareness of their ecological adversities have rightfully shed light on these unsustainable practices. Developments in materials science and technology, however, have contributed to the improvement of soil conditions, nutrients, as well as water and plant management. Polymers are a class of versatile materials that have been used in many agricultural applications due to the ability to engineer application-specific polymers ${ }^{[3-5]}$. Depending on their uses, lifetime and economic viability, different classes of polymers have been used extensively in agriculture ${ }^{[4,6-8]}$. With regard to this review, our aim is to demonstrate how polymer science impacts agricultural technology and practices concerning four major applications: 
(i) controlled delivery systems; (ii) heavy metal removal in soil and water; (iii) superabsorbents; and (iv) trends in polymer biodegradation.

Figure 1 is a panoramic overview of literature based on a bibliography search in Science Direct based on a period of ten years using "polymer agriculture", "polymer agriculture and controlled-release", "polymer agriculture and superabsorbent" and "polymer agriculture and biosorbent." There is a clear increase in the quantity of studies that investigate general polymer applications in agriculture, however, the more specific and novel themes of controlled-release, superabsorbent and biosorbent are evidently publication deficient. Hence, this overview demonstrates the importance and optimism for the study on polymers and their application in agriculture.

\section{Controlled Delivery of Agrochemicals by Polymeric Matrices}

An important point in agriculture is to supply nutritional needs of plants, which ranges from macronutrients such as $\mathrm{N}, \mathrm{P}, \mathrm{K}, \mathrm{Ca}, \mathrm{Mg}$ and $\mathrm{S}$ to micronutrients such as $\mathrm{B}, \mathrm{Cl}, \mathrm{Co}$, $\mathrm{Cu}, \mathrm{Fe}, \mathrm{Mn}, \mathrm{Mo}, \mathrm{Ni}$ and $\mathrm{Zn}^{[9]}$. However, these nutrients are often not available in the environment at sufficient levels for good plant growth. Thus, the use of agrochemicals is essential in agriculture, as fertilizers, herbicides and pesticides. On the other hand, as knowledge of the lifecycle of agrochemicals has increased, concern over how some undesirable environmental impacts, including bioaccumulation processes in the food chain and potential contamination of neighboring ecosystems have also grown more relevant ${ }^{[4]}$.

The development and use of agrochemicals combined with polymeric materials has been an alternative to this problem in order to deliver agrochemicals into the soil to directly fulfill the nutritional needs of plants without causing contamination $^{[4]}$. The combination of agrochemicals and polymers can be classified as physical or chemical processes. For example, control over the rate of release is physical while how chemical is stabilized within the polymer matrix is a chemical mechanism. The biological and chemical properties of the agent and its physiochemical interactions help to direct selection of the best system to release the active agent ${ }^{[4]}$. In addition, the release profile is classified into two classes, slow- and controlled-release systems. Slow-release fertilizer (SRF) relates to the mechanism itself that delays the release, compared to controlled-release which depends on the type of mechanism to liberate the nutrient into the environment ${ }^{[10,11]}$. Controlled-release fertilizer (CRF) has
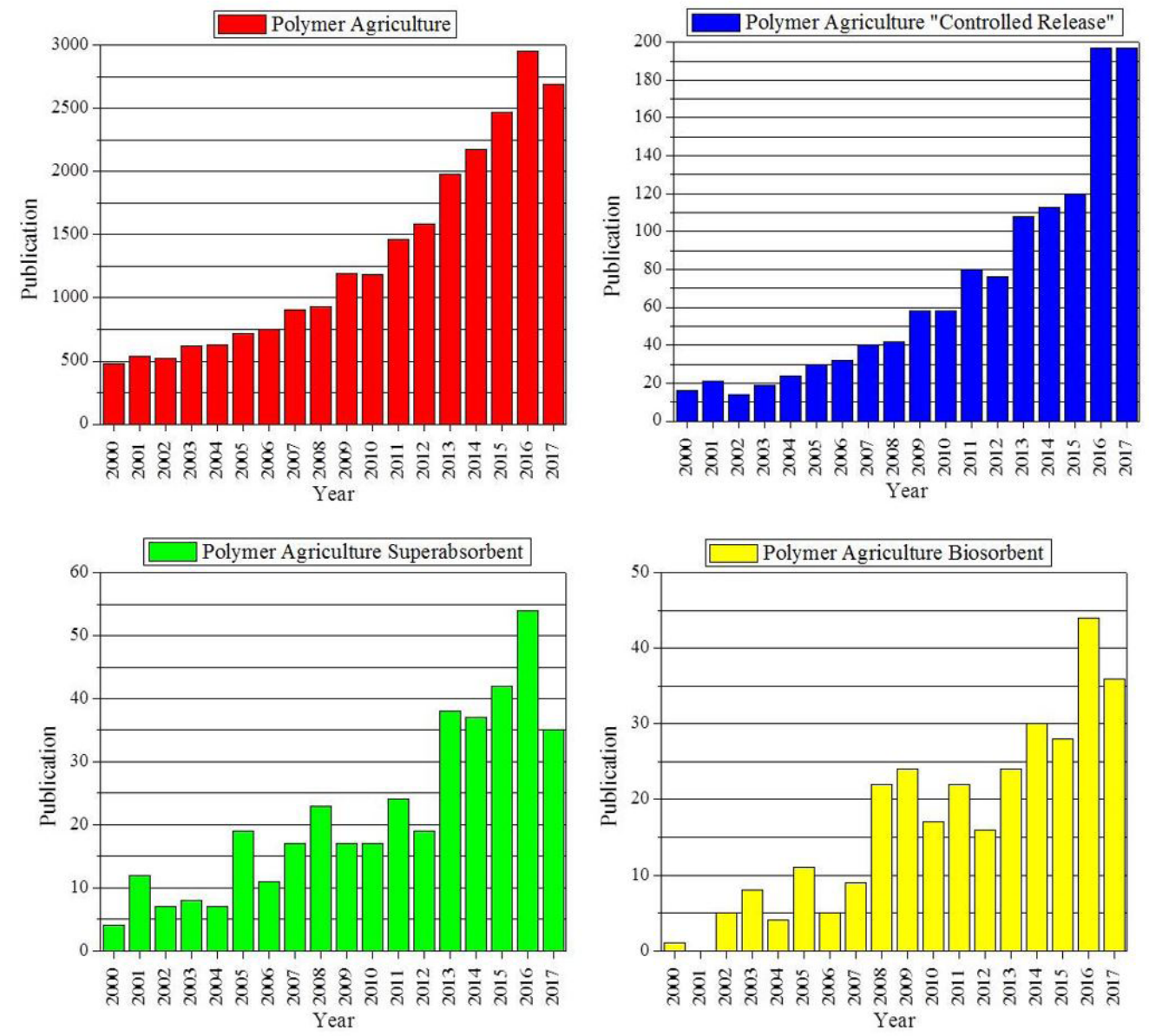

Figure 1. Literature review of polymer applications in agriculture, including controlled-release, superabsorbent and biosorbent practices. 
known factors that influence the rate and pattern of release, hence they can be controlled ${ }^{[10,12,13]}$. The pattern of release in water of slow- and controlled-release materials have been reported ${ }^{[12,14-16]}$.

The concept controlled nutrient release is not a recent innovation. In 1962, Oertli and Lunt ${ }^{[17]}$ published their study about controlled-release of fertilizer minerals by membrane encapsulating ${ }^{[18]}$, and in 1971 Allan et al. ${ }^{[19]}$ reported on controlled-release of pesticides. Their seminal work has had a dramatic influence on the field and development of the technology continues to grow as shown in Figure 1.

Controlled-release materials used to acrylic-based organic polymers, such as acrylamide ${ }^{[19]}$. Through time, environmentally green materials were proposed as alternatives to encapsulate agrochemicals, such as inorganic soil components including clay minerals ${ }^{[20]}$ or calcium carbonate $^{[21]}$. Recent studies have introduced the concepts of nanotechnology to improve the release mechanism through the use of nanoparticles. In chemical terms, three types of material are being used to develop this technology: organic polymers, inorganic compounds and polymers, and hybrid materials or composites ${ }^{[22]}$.

As previously described, polymers that are most frequently employed to encapsulate agrochemicals are acrylamide-based gels. Other polymers include: natural rubber; polyethylene (PE); copolymers of VC-acrylic acid esters and copolymers of cyclopentadiene with a glyceryl ester of an unsaturated fatty acid; polysaccharides; and cellulose-based materials ${ }^{[4]}$. Herbicides, which are the most frequently used agrochemicals, are often employed as pendant groups in polymers. Examples include: pentachlorophenol (PCP), 2,4-dichlorophenoxyacetic acid (2,4-D) and 4-chloro-2-methylphenoxyacetic acid ${ }^{[23]}$; fertilizer with NPK (nitrogen, phosphorous and potassium), urea, $\mathrm{KNO}_{3}, \mathrm{Ca}_{2} \mathrm{CO}_{3}$; and fertilizer with micro and macro nutrients (phosphorus, potassium, manganese, zinc, copper, molybdenum, boron and others) produced according to the agronomical needs (type of crop and soil) ${ }^{[4]}$; and pesticides as bifenthrin, tebuconazole, chlorpyrifos and atrazine ${ }^{[6]}$.

Primary studies have reported that fabrication of controlled-released materials has been made exclusively with synthetic polymers. More recent studies, on the other hand, are concerned with the application of biodegradable polymers and their composites as materials for controlled-release of agrochemicals in soil ${ }^{[6,24]}$. Table 1 shows some polymers that have been studied as matrices for controlled-release in agriculture in the past ten years.

\subsection{Advantages and disadvantages of controlled-release}

There are many advantages of controlled-release materials such as regular and continuous nutrient supply to plants, lower frequency of applications in soil, reduced nutrient loss due to leaching, volatilization and immobilization, mitigation of root damage by high concentration of salts, greater convenience over handling fertilizers, contribution to the reduction of environmental pollution by $\mathrm{NO}_{3}^{-}$, and improved ecological health to agricultural activity (less contamination of groundwater and surface water) and reduction in production costs ${ }^{[39-43]}$.

Despite the increased development of controlled-release materials and their many advantages, use of them is much more regulated compared to conventional agrochemicals

Table 1. Polymers and agrochemical used into slow/controlled-release materials.

\begin{tabular}{|c|c|c|}
\hline Agrochemical used & Polymer used & Reference \\
\hline \multirow{3}{*}{ Urea } & Chitosan & \multirow{3}{*}{ [25-27] } \\
\hline & Polyhydroxybutyrate (phb), ethyl cellulose & \\
\hline & Polyethylene, polyvinyl acetate, polyurethane, polyacrylic, polylatic acid & \\
\hline $\mathrm{KH}_{2} \mathrm{PO}_{4}$ & Chitosan, gellan gum & [28] \\
\hline \multirow{3}{*}{ NPK } & Chitosan & \multirow{3}{*}{ [29-31] } \\
\hline & Cellulose, natural gum, rosin, waxes & \\
\hline & Paraffins, ester copolymers, urethane composites, epoxy, alkide resins, polyolefines, & \\
\hline $\mathrm{CaH}_{4} \mathrm{P}_{2} \mathrm{O}_{8}$ & Chitosan & [32] \\
\hline \multirow{3}{*}{$\mathrm{KNO}_{3}$} & Chitosan & \multirow{3}{*}{ [33-35] } \\
\hline & Chitosan-clay (montmorillonite) & \\
\hline & Xanthan & \\
\hline Paraquat $\left(\left[\left(\mathrm{C}_{6} \mathrm{H}_{7} \mathrm{~N}\right)_{2}\right] \mathrm{Cl}_{2}\right)$ & Alginate, chitosan & [36] \\
\hline Hexazinone $\left(\mathrm{C}_{12} \mathrm{H}_{20} \mathrm{~N}_{4} \mathrm{O}_{2}\right)$ & Chitosan - clay & \multirow{2}{*}{ [37] } \\
\hline Clopyralid $\left(\mathrm{C}_{6} \mathrm{H}_{3} \mathrm{Cl}_{2} \mathrm{NO}_{2}\right)$ & (montmorillonite) & \\
\hline $2,4-\mathrm{d}\left(\mathrm{C}_{8} \mathrm{H}_{6} \mathrm{Cl}_{2} \mathrm{O}_{3}\right)$ & Polysaccharides & \multirow{8}{*}[6,11,38]{} \\
\hline 2-chloro-;4-chloro- & Cellulose, agarose, dextran, alginates, carrageenans, starch, chitosan, gelatin, & \\
\hline 2,4,5-Trichloro- phenoxyacetates & Albumin & \\
\hline Validamycin $\left(\mathrm{C}_{20} \mathrm{H}_{35} \mathrm{NO}_{13}\right)$ & Polystyrene, polyacrylamide, polymethylacrylate, polyamides, polyesters, & \\
\hline Bifenthrin $\left(\mathrm{C}_{23} \mathrm{H}_{22} \mathrm{ClF}_{3} \mathrm{O}_{2}\right)$ & Polyanhydrides, polyurethanes, amino resins, polycyanoacrylates & \\
\hline \multicolumn{2}{|l|}{ Chlorpyriphos $\left(\mathrm{C}_{9} \mathrm{H}_{11} \mathrm{Cl}_{3} \mathrm{NO}_{3} \mathrm{PS}\right)$} & \\
\hline \multicolumn{2}{|l|}{ Bifenthrin $\left(\mathrm{C}_{23} \mathrm{H}_{22} \mathrm{ClF}_{3} \mathrm{O}_{2}\right)$} & \\
\hline Azadirachtin $\left(\mathrm{C}_{35} \mathrm{H}_{44} \mathrm{O}_{16}\right)$ & & \\
\hline
\end{tabular}


due to their high fabrication prices ${ }^{[33]}$. Furthermore, there are others disadvantages that need to be overcome, for example, said materials are known to release nutrients prematurely and quickly (burst effect), which can damage the plant or result in a non-releasing during high crop demand periods. Further, controlled-release materials can be a problem because of unwanted residues of synthetic materials on the ground, which can affect the soil acidity ${ }^{[13]}$.

Another disadvantage to the use of controlled-release might occur during the material development process due to the lack of standard methods to validate the nutrient release profile from laboratory scale to field conditions, and the difficulty to measure the impacts of the nutrients into the soil ${ }^{[10]}$. Various simulations and experimental tests have been widely investigated in order to model the release mechanism. It is also known that by Fick's First Law of Diffusion, the mechanism of controlled-release of agrochemicals is governed by diffusion coefficients and coat thickness. In other words, there is a relationship between the rate of solute diffusion of the material and the rate of water/vapor permeation through the material ${ }^{[44,45]}$.

There have been several studies regarding mathematical models of controlled-release since 1979 when Jarrell and Boersma modeled urea delivery from sulfur-encapsulated particles in soil conditions ${ }^{[46]}$. Their materials were porous and preserved with a polymeric coating. Upon application, however, the soil conditions and microorganisms of the ecosystem degraded the polymeric material, thereby exposing the more vulnerable layers. Still, nutrient diffusion through the pores was influenced by temperature and soil water content.

As described in the previous study, the release mechanism is frequently divided into three periods. First is the lag period or initial stage, wherein almost no release is detectable. The second period occurs once a constant-release is achieved and the third period begins once a gradual decay or release is observed $^{[12]}$. Still, despite the aforementioned disadvantages related to standard methods to evaluate release profiles, controlled-release materials are promising for improved agricultural management.

\section{Superabsorbent Polymers and Their Applications in Soil}

Aside from fertilizers, all agricultural processes require a maintenance system of irrigation in order to provide enough nutrients to the soil. In arid areas, irrigation processes are particularly expensive, thereby making certain polymer materials unfeasible. As a result, the use of superabsorbent polymer (SAP) hydrogels has become an attractive alternative to circumvent this problem because they supply the necessary cost reductions and continuous irrigation characteristic of this procedure. In the presence of water, SAPs are able to swell and hold aqueous solutions, maintaining the humidity of the soil for longer periods. Surprisingly, the utilization of SAPs for agricultural processes has only been recently discussed in the Academy ${ }^{[47]}$.

Literature extensively describes the use of SAPs for biological applications, such as contact lenses ${ }^{[48-50]}$, baby diapers and female hygienic tampons ${ }^{[51,52]}$. Most recently, SAPs have appeared as an excellent alternative to drug encapsulation for delivery systems ${ }^{[3-55]}$. Previous applications derived from the swelling property of SAPs, which guarantees large capacity of water absorption, have fortified the potential for biocompatibility ${ }^{[56]}$. Erickson ${ }^{[57]}$ first reported the application of a SAP as a soil conditioner. Redenbaugh ${ }^{[58]}$ in turn studied its functionality to encapsulate and slowly release agrochemicals in the soil. Moreover, the origin of SAPs is closely related to its applicability; i.e. SAPs' properties deserve further research and development as a promising field of study.

As a positive contribution to this expanding field, the aim of this review is to provide an overview of SAPs, focusing in particular on their agricultural applications. For this purpose, we will briefly describe the characteristics of a SAP, and explore literature regarding its use as a soil conditioner and its application for controlled-release of fertilizers.

\subsection{Superabsorbent polymer hydrogels}

Superabsorbent Polymer (SAP) hydrogel is defined as a lightly crosslinked three-dimensional polymer network, usually composed of ionic monomers, whose property of interest is the capacity of swelling in the presence of aqueous or biological fluids ${ }^{[59]}$. The density of chain crosslinking creates an expressive amount of free volume between the polymer network, which in turn, combined to the presence of huge number of hydrophilic groups, can absorb and hold large quantity of water, on the order of 10 to $1000 \mathrm{~g} / \mathrm{g}$ $(1.000-100.000 \%)^{[60]}$.

The water holding and swelling capacity of a SAP can be explained by a multi-step mechanism. The first step comprises the hydration of hydrophilic groups present in the polymer network with strong bonds to water. Secondary weaker bonds are made with water by the interaction between water and the exposed hydrophobic groups. As a next step, physical or chemical crosslinks minimize the effect of osmotic forces that would lead to infinite dilution of the polymer network, and for this reason, the network retains additional water ${ }^{[59]}$.

SAPs are mainly classified according to their origin, crosslinking nature, and their responsive mechanism. Considering its origin, a SAP can be natural, synthetic or a hybrid. Regarding its crosslinking structure, a SAP is chemically crosslinked, which forms covalent bonds between the polymer networks resulting in a permanent state, or physical crosslink in which polymer networks are bonded through intermolecular forces, such as ionic interactions, hydrogen bonds, or Van der Walls forces. The responsive mechanism of a SAP is either conventional or induced by an external stimulus. A conventional SAP will not have altered swelling equilibrium under environmental stimulus, for example, changes in $\mathrm{pH}$, temperature, or electric field. On the other hand, Samchenko et al. ${ }^{[61]}$ calls a stimulus responsive SAP a smart or intelligent hydrogel, as these materials adapt their swelling equilibrium to environmental conditions. Applications based on reversible swelling/deswelling can be modulated based on chemical, biochemical or physical responses and are dependent on environmental conditions, such as high ionic conductivity, high permeability and sorption capacity. 


\subsection{Superabsorbent polymer hydrogels as soil conditioners}

The appearance of SAP hydrogels as soil conditioners dates back to the 1980s when the first patents describing the application of hydrogels were published. Erickson ${ }^{[57]}$ patented a method for improving the water retention and aeration capacity of soil matrixes by inserting polymeric films with water-swelling properties in soil. The films could be produced from several polymer-based materials, such as alkyl acrylate (i.e. methyl, ethyl, propyl and hexyl acrylates), alkyl methacrylates (including butyl, hexyl, octyl, and decyl methacrylate), and omega hydroxyalkyl acrylates (comprising 2-hydroxyethil acrylate and hydroxymethyl acrylate). The discovery of this film has presented alternatives to the previous use of absorbent powder added directly to the soil, which can cause noteworthy problems as the particles shift positions with soil management, causing sealing effects in the soil. By adding the absorbent polymer in film format, it can be twisted, crumpled, or chopped and positioned in the soil in a way to avoid sealing effects and improve its water retention capacity ${ }^{[62]}$.

Callanghan et al. ${ }^{[62]}$ tested polyacrylamide and poly(vinyl alcohol) as superabsorbent polymers applied on drought affected soils in Sudan. They proved that poly(vinyl alcohol) was able to increase the field capacity of the soil by $22 \%$, and both polymers increased the period of plant survival in the conducted nursey experiments, providing evidence for the economic importance of SAPs. Aside from polyacrylamide and poly(vinyl alcohol), Woodhouse and Johnson ${ }^{[63]}$ tested a starch-copolymer on the growth of barley and lettuce in coarse soil. Their observations were that as the percentage of SAPs for water retention increased, the longer the period until plants reached their wilting point.

Stahl et al. ${ }^{[64]}$ was the first to study the rate of biodegradability of superabsorbent copolymers made from polyacrylamide and polyacrylate as well as pure polyacrylate in soils. They estimated the degree of biodegradability based on the mineralization of the polymers, which was measured by the release of $\mathrm{CO}_{2}$ produced by biodegradation reaction. As Shuterland et al. ${ }^{[65]}$ had previously proven, microorganisms naturally present in the soil were not able to biodegrade the introduced polymers. For this reason, their research was conducted in a way to investigate potential microbes in order to maximize the rate of biodegradability.

In the past few years, research has been performed in order to investigate different kinds of polymeric composites that would increase the efficiency of SAPs in improving soil conditions. Islam et al. ${ }^{[6]]}$ for example, used granular polyacrylamide under moderate and deficient irrigation conditions. They proved that the presence of SAPs was able to increase irrigation's efficiency in $8.1 \%$ under moderate exposure to drought, and $15.6 \%$ under higher drought condition. Moreover, they noticed that the presence of granular polyacrylamide was able to reduce the activity of antioxidant enzymes, which under drought stress produced oxygen radicals responsible for harming the plant's capacity of carbon fixation and, consequently, its growth. Therefore, in the presence of polyacrylamide SAPs, plant growth was satisfactory even under lower irrigation conditions ${ }^{[66]}$.
Sharma et al ${ }^{[67]}$ described the synthesis of interpenetrating polymer networks based on poly(aspartic acid) whose characteristic of interest is the elevated capacity of biodegradation. Furthermore, they suggest that improving the synthetic route through the incorporation of biochemical cross-linkers, or charged functional groups to hydrophilic biopolymers would increase the material's capacity to biodegrade as well as increase its absorbency. However, neither of those synthetic routes resulted in a fully biodegradable material.

Cannazza et al ${ }^{[68]}$ in turn, applied cellulose-based SAPs as an environmentally friendly alternative to acrylate-based SAPs. They used derivatives of carboxymethyl cellulose sodium salt and hydromethyl cellulose as starting materials for the synthesis of the cellulose-based hydrogels. Posterior tests showed an efficiency of swelling, water retention and soil conditioning very similar to those obtained with acrylate-based SAPs.

Dragan ${ }^{[69]}$ described the studies of interpenetrating polymer networks (IPN) hydrogels based on biopolymeric materials, such as, chitosan, alginate, starch, and other polysaccharides. Chauhan and Mahajan ${ }^{[70]}$ apud Dragan ${ }^{[69]}$ described the use of IPN based on a combination of biopolymers with poly(methacrylamide) for metal ion sorption in aqueous solution. They noticed that the sorption capacity of the material drastically increased after inserting cellulose derivatives in the polymer network.

Besides soil conditioning or metal ion sorption, SAPs can also be employed for slow- release of fertilizers in the soil. Zhan et al. ${ }^{[71]}$ reported the synthesis of a SAP combining groups of polyvinyl alcohol with phosphoric acid $\left(\mathrm{H}_{3} \mathrm{PO}_{4}\right)$ through esterification. In this case, the material had the property of not only absorbing and retaining water, but also of releasing phosphate fertilizer. However, the study only tested the swelling capacity and release properties in an aqueous environment, not in soil, the latter showing a release of $79 \%$ of the material in 28 days ${ }^{[71]}$. The mechanism of release could be explained for the swelling of the hydrogel material when immersed in water, such as the hydrolysis of pendant phosphate groups of the polymer network. Consequently, the dissolved phosphate groups diffused out of the hydrogel due to a difference of concentration gradient inside and outside the material ${ }^{[56]}$.

Liang et al. ${ }^{[72]}$ on the other hand, tested the entrapment of NPK inside a poly (acrylic acid co-acrylamide)/kaolin clay superabsorbent composite. The addition of clay to the synthetic polymer was an attempt to reduce costs and improve the material's swelling capacity. In the described work, Liang et al. ${ }^{[72]}$ also tested the swelling capacity and the release mechanism in aqueous medium. They established a temperature dependent release mechanism showing that as temperature increased, the higher the solubility of the nutrient and the faster its release.

Although the addition of clay to a synthetic material can enhance its properties and diminish costs of production, environmental concerns caused by non-biodegradable materials added to the soil are still issues to overcome. In this context, researchers are focused on finding environmental friendly materials that can fulfill human economic necessities without amplifying waste accumulation. Jamnongkan and Kaewpirom ${ }^{[73]}$ for example, synthetized and tested three 
different hydrogels: the first based on poly(vinyl alcohol), the second based on a combination of poly(vinyl alcohol) and chitosan and the last composed only of chitosan. They tested the swelling capacity of the three materials in soil and the hydrogel made of PVA alone was the one that guaranteed the best soil conditioning. With regard to the release capacity of potassium in the soil, the pure chitosan hydrogel was most promising.

At this point the reader may recognize the necessity to advance the use of hydrogels in agriculture, as well as the discovery and synthesis of environmental friendly materials, such as biopolymers, with high biodegradability in soil. Although the necessity to maintain impressive swelling capacity with combined fertilizer release properties still constitutes diverse challenges, the new era of chemistry research guided by green chemistry principles can lead to novel discoveries in this immerging area of materials and agriculture science.

\section{Metal Ions Removal from Water and Soils}

Metal ions can be classified into three different categories: toxic metals, such as $\mathrm{Hg}, \mathrm{Cr}, \mathrm{Pb}, \mathrm{Zn}, \mathrm{Cu}, \mathrm{Ni}, \mathrm{Cd}, \mathrm{As}, \mathrm{Co}$, and $\mathrm{Sn}$; precious metals, including $\mathrm{Pd}, \mathrm{Pt}, \mathrm{Ag}, \mathrm{Au}$, and $\mathrm{Ru}$; and radioactive metals, like $\mathrm{U}, \mathrm{Th}, \mathrm{Ra}$, and $\mathrm{Am}^{[74]}$. Some of these metals can be coupled to agrochemicals, such as to fertilizer, insecticides and herbicide, and then released into the soil. The soil itself, with no addition of agrochemicals, is an essential and natural source of nutrients for plants and other living organisms, consequently, trace amounts of metal ions occur naturally in the soil's composition, functioning as important micronutrients. These metal ions are mainly classified into essential micronutrients ( $\mathrm{Fe}, \mathrm{Zn}, \mathrm{Mn}, \mathrm{Ca}, \mathrm{Na}$, $\mathrm{K}, \mathrm{Cu}$, and $\mathrm{Mo})$, beneficial micronutrients $(\mathrm{Co}, \mathrm{Ni}$, and $\mathrm{V})$, and non-essential micronutrients $(\mathrm{Cd}, \mathrm{Cr}, \mathrm{Hg} \text {, and } \mathrm{Pb})^{[75,76]}$.

However, the enforcement of intensive agriculture has resulted in abusive techniques that are combined with the massive use of agrochemicals solely to increase profit and productivity. Due to this fact, an enormous amount of organic and inorganic toxic contaminants, namely metal ions, are deposited daily into soils, rivers, and groundwater ${ }^{[77]}$. Such problems with metal ions are threatening because these ions are cumulative and do not degrade naturally in the environment. Hence, their toxicity can cause severe ecological damage that can be harmful to human, other animals, insects, etc. through the consumption of contaminated water and/or food ${ }^{[78]}$. In this context, concern over soil and water pollution has stimulated scientists to develop techniques that are fundamentally aimed to circumvent or mitigate ecological harm as well as cleanse current ecosystems that are already threatened ${ }^{[79]}$. Perusing the literature, one might notice the abundance in the quantity of publications that address methods for the removal of heavy metal pollution in aqueous environments, compared to a few articles that address techniques for decontamination of soils.

One method for the recovery of contaminated areas involves polymeric biosorption: biosorption being a biological property characteristic of microbial biomass, which has been adopted into biomimetic-type techniques for the binding heavy metals even from very dilute solutions. Biosorption is a technique of bioremediation whose application has been studied in both water and soil systems as an alternative for metal ions removal. This technique is able to remove either organic or inorganic pollutants through ionic exchange. Research results highlight the high capacity of sorption and the low cost of this method ${ }^{[80]}$.

Besides biosorption, polymers have also been commonly used as sorbent materials of toxic elements arising from agrochemicals as a way to decontaminate water and soils ${ }^{[8]}$. To better understand the mechanism of sorption by a polymer it is necessary first to identify the functional groups that are present in the material. Metal ions are absorbed on the surface of the polymeric material due to their chemical affinity for certain functional group ${ }^{[82]}$. Polysaccharides such as cellulose, chitin, chitosan and exobiopolymers are a group of polymers most commonly applied for the purpose of metal sorption due to their ionizable carboxylic acid, alcohol, amine and amide functional groups for ionic bonding ${ }^{[81,83,84]}$.

Additionally, natural fiber extracted from sugarcane bagasse, green coconut fiber, and bamboo fiber, have also been applied as biosorbents. The main advantage of these materials is they are generally industrial and/or agricultural residues, low cost, and easily recovered. Such crude fibers are mainly composed of cellulose and hemicellulose which possess acidic groups responsible for the sorption of metal ions $^{[85]}$.

Focusing on the metal decontamination of soils as phytoremediation and rhizoremediation, research involving biopolymers, such as polysaccharides, as adsorbents is still ongoing and the development of materials capable of decontaminating affected areas with high efficiency and low cost, is still active ${ }^{[86]}$.

$\mathrm{Pal}$ and Paul ${ }^{[87]}$, in turn tested the use of exopolymer films for the remediation process of contaminated water. Exopolymers are extracellular substances originating from microorganisms in the form of biofilms, which are capable of absorbing metal ions through electrostatic interactions. Their results showed that zinc, copper, chromium, cadmium, cobalt, nickel and $\mathrm{CrO}$ metals were absorbed most efficiently.

In aqueous environments, the methods of metallic ions removal have thus far been based on biological treatments, such as filtration, electrochemical treatment, chemical precipitation, ion exchange, membrane technologies, and adsorption over active coal ${ }^{[74,87]}$. However, current studies are investigating novel applications for the use of recycled biomass as feedstock for the development of heavy metalabsorbing biomaterials in aqueous environments. Such agricultural residues include sugarcane bagasse, which has gained much attention for application in this field due to its abundance in several regions from Brazil ${ }^{[85]}$. Table 2 presents other commonly studied biomasses and their sorption capacity.

Besides soil, Table 2 shows the biomass and polymer constituent relationship and its relation with the metal ions in water adsorption. It can be observed that among the materials used as biosorbents, cellulose is the most commonly used metal ion "sequestrant," because of cellulose's abundant surface hydroxyl groups that can be functionalized to possess more polar or ionizable pendant groups for enhanced ion exchange for decontaminating water. 
Table 2. Examples of biomass feedstock and associated polymer compositions for ion removal.

\begin{tabular}{|c|c|c|c|c|}
\hline Biomass & Polymer & Sorption capacity* & ions removed & Reference \\
\hline \multirow{2}{*}{ Sugarcane bagasse ash } & \multirow{2}{*}{$45 \%$ cellulose, $28 \%$ hemicellulose and $18 \%$ lignin } & $36.3 \mathrm{mg} \mathrm{g}^{-1}(\mathrm{Cu})$ & $\mathrm{Cu}(\mathrm{II})$ & \multirow{2}{*}{ [88] } \\
\hline & & $41.31 \mathrm{mg} \mathrm{g}^{-1}(\mathrm{Cr})$ & $\mathrm{Cr}(\mathrm{III})$ & \\
\hline Bagasse sugar beet & Cellulose and pectin & $185 \mathrm{mg} \mathrm{g}^{-1}$ & $\mathrm{Tl}(\mathrm{II})$ & [89] \\
\hline Green coconut shell & Fibers (polysaccharide) & $22.96 \mathrm{mg} \mathrm{g}^{-1}$ & $\mathrm{Cr}(\mathrm{VI})$ & {$[90]$} \\
\hline Chitosan & polysaccharide & $36.8 \mathrm{mg} \mathrm{g}^{-1}$ & $\mathrm{~Pb}(\mathrm{II})$ & [91] \\
\hline \multirow{3}{*}{ Sawdust } & \multirow{3}{*}{ polysaccharide } & $26 \mathrm{mg} \mathrm{g}^{-1}(\mathrm{~Pb})$ & $\mathrm{Pb}(\mathrm{II})$ & \multirow{3}{*}{ [92] } \\
\hline & & $22.5 \mathrm{mg} \mathrm{g}^{-1}(\mathrm{Cu})$ & $\mathrm{Cu}(\mathrm{II})$ & \\
\hline & & $19.75 \mathrm{mg} \mathrm{g}^{-1}(\mathrm{Zn})$ & $\mathrm{Zn}(\mathrm{II})$ & \\
\hline Microalgae: Spirulina platensis & Cellulose - polysaccharide & $100.39 \mathrm{mg} \mathrm{g}^{-1}$ & $\mathrm{Cr}(\mathrm{VI})$ & [93] \\
\hline \multirow{2}{*}{ Rice straw } & \multirow{2}{*}{ Cellulose, hemicellulose and lignin } & $30.0 \mathrm{mg} \mathrm{g}^{-1}(\mathrm{Cr})$ & $\mathrm{Cr}(\mathrm{III})$ & \multirow{2}{*}{ [94] } \\
\hline & & $22.5 \mathrm{mg} \mathrm{g}^{-1}(\mathrm{Cu})$ & $\mathrm{Cu}(\mathrm{II})$ & \\
\hline \multirow{2}{*}{ Banana peel } & \multirow{2}{*}{ Cellulose, hemicellulose, lignin and pectin } & $2.18 \mathrm{mg} \mathrm{g}^{-1}(\mathrm{~Pb})$ & $\mathrm{Pb}(\mathrm{II})$ & \multirow{2}{*}{ [95] } \\
\hline & & $5.71 \mathrm{mg} \mathrm{g}^{-1}(\mathrm{Cd})$ & $\mathrm{Cd}(\mathrm{II})$ & \\
\hline \multirow{4}{*}{ Cotton fiber } & \multirow{4}{*}{ Cellulose, hemicellulose and lignin } & $6.12 \mathrm{mg} \mathrm{g}^{-1}(\mathrm{Cu})$ & $\mathrm{Cu}(\mathrm{II})$ & \multirow{4}{*}{ [96] } \\
\hline & & $4.53 \mathrm{mg} \mathrm{g}^{-1}(\mathrm{Zn})$ & $\mathrm{Zn}(\mathrm{II})$ & \\
\hline & & $8.22 \mathrm{mg} \mathrm{g}^{-1}(\mathrm{Cd})$ & $\mathrm{Cd}(\mathrm{II})$ & \\
\hline & & $21.62 \mathrm{mg} \mathrm{g}^{-1}(\mathrm{~Pb})$ & $\mathrm{Pb}(\mathrm{II})$ & \\
\hline Scolymus hispanicus L (Plant) & Cellulose - polysaccharide & $54.05 \mathrm{mg} \mathrm{g}^{-1}$ & $\mathrm{Cd}(\mathrm{II})$ & [97] \\
\hline \multirow{2}{*}{ Fungus - Fusarium verticillioide } & \multirow{2}{*}{ polysaccharide } & $50.50 \mathrm{mg} \mathrm{g}^{-1}(\mathrm{Mg})$ & $\operatorname{Mg}(\mathrm{II})$ & \multirow{2}{*}{ [98] } \\
\hline & & $92.59 \mathrm{mg} \mathrm{g}^{-1}(\mathrm{Ca})$ & $\mathrm{Ca}(\mathrm{II})$ & \\
\hline
\end{tabular}

*Maximum Amount of Solute Retained in the Adsorbent in Balance (qe).

As mentioned before, several materials are being applied as biosorbents for removal of metallic ions from aqueous environments. Hence, literature frequently presents tests of new materials for metal depollution of hydric resources whose properties are developed in way to increase efficiency and lower costs. On the other hand, publications regarding the research and development of materials for soil remediation are still scarce. The reasoning for this may be explained by the fact that removal of heavy metals from soil may also adversely impact micro or macronutrient populations for plants, which causes the vegetables' roots to absorb or adsorb metal ions according to its necessity through a mechanism called phytoremediation.

\section{Trends of Biodegradable Polymer materials in Agriculture Application}

The degradation of organic chemicals in the environment is known as biodegradation, in which the compounds are mainly converted into mineralized forms and redistributed through carbon, nitrogen and sulphur cycles by micro-organism activities ${ }^{[99,100]}$. Natural and/or biodegradable polymers are still a requisite to overcome some problems concerning environmental aspects of polymer applications in agriculture. As seen before, synthetic polymers are most commonly used for agricultural applications, either in intelligent agrochemicals or superabsorbents, which severely creates large quantities of non-biodegradable waste and soil contamination.

Polymer biodegradation is a very comprehensive and recent area of research; however, the connection with the polymers application in soil on agriculture context is still incipient in the literature. Several reviews with reference to degradation processes of polymers in soil and aqueous medium have been published ${ }^{[101,102]}$. However, few discussions have accomplished polymer degradation from agrochemicals encapsulated in a polymer matrix.

Additionally, some difficulties have been pointed out to find a polymer with both long accurate release control and a high rate of biodegradation under the mild conditions of agricultural fields ${ }^{[100]}$. Some reports present the biodegradation matrix used in controlled-release of drugs $^{[103,104]}$. Watanabe et al. ${ }^{[100]}$ studied the influence of the $\mathrm{Tg}$ on release and biodegradation of urea coated with polycaprolactone based polyurethanes. According to the authors the biodegradation characteristic was affected by the glass transition temperature and the recrystallization of polyurethane membrane. Nevertheless, few works have dealt with the relationship between polymer applications in agriculture and their biodegradation in soils under natural conditions. Ge et al. ${ }^{[101]}$ used biodegradable polyurethane as ammonium sulfate fertilizer coating and subsequent biodegradation studies were performed. They suggested that the contribution of the PU matrix on the initial release stage occurs by the diffusion process and an additional release is associated with degradation in the last stage. However, they did not perform the release and biodegradation tests in the same conditions to better understand the whole process. Saruchi et al. ${ }^{[105]}$ evaluated the influence of acrylic acid based hydrogel on the soil fertility. Additionally, they investigated the release properties of potassium-containing hydrogel; however, no information was discussed about the polymer biodegradation in a presence of fertilizer.

Biodegradation studies have also been performed on superabsorbent polymers. Ye et al. ${ }^{[106]}$ prepared a degradable superabsorbent material based on a silicate/acrylic-based polymer. They proposed a hydrolysis process from $\mathrm{Si}-\mathrm{O}-\mathrm{C}$ bonds in aqueous solution which degraded the hybrid hydrogels in a matter of days. Wilske et al. ${ }^{[107]}$ characterized the biodegradability of SAP based on polyacrylate for 
four agricultural soils and at three temperatures. Detailed results suggest that the polyacrylate main chain degraded in the soils, if at all, at rates of $0.12-0.24 \%$ per 6 months ${ }^{[93]}$. Further, Sthal et al. ${ }^{[64]}$ studied the rate of biodegradability of superabsorbent copolymers made out of polyacrylamide and polyacrylate, and pure polyacrylate in soils. They estimated the degree of biodegrability based on the mineralization of the polymers, measuring the released $\mathrm{CO}_{2}$ produced by biodegradation reactions ${ }^{[64]}$. As Shuterland et al. ${ }^{[65]}$ had previously proved, the microorganisms naturally present in the soil were not able to biodegrade the added polymers. For this reason, the following research was conducted in a way to investigate potential microbes in order to maximize the rate of biodegrability.

\section{Final Consideration and Perspectives}

Based on the survey of topics presented in this study, we conclude that there is ample opportunity to enhance the application of polymers in agriculture. It is imperative that the use of polymers be in a way that is environmentally, technically, socially, and economically sustainable in practice. Key opportunities exist to produce intelligent polymers with biodegradable and renewable properties for various agricultural applications.

\section{Acknowledgements}

The authors thank FAPESP for financial support (Proc. 2014/06566-9) and CNPq and Capes for a scholarship.

\section{References}

1. Food and Agriculture Organization of the United Nations. (2011). The state of the world's land and water resources for food and agriculture (SOLAW) - managing systems at risk. Rome: FAO.

2. Tilman, D., Cassman, K. G., Matson, P.A., Naylor, R., \& Polasky, S. (2002). Agricultural sustainability and intensive production practices. Nature, 418(6898), 671-677. PMid:12167873. http:// dx.doi.org/10.1038/nature01014.

3. Jhurry, D. (1998, March). Agricultural polymers. In Proceedings of the Second Annual Meeting of Agricultural Scientists (pp. 109). Mauritius: FARC. Retrieved in 11 October 2016, from http://farc.govmu.org/English/Documents/Policy\%20and\%20 promotion/information\%20outreach/finalm97.pdf\#page $=131$

4. Puoci, F., Iemma, F., Spizzirri, U. G., Cirillo, G., Curcio, M., $\&$ Picci, N. (2008). Polymer in agriculture: a review. American Journal of Agricultural and Biological Sciences, 3(1), 299-314. http://dx.doi.org/10.3844/ajabssp.2008.299.314.

5. Ekebafe, L. O., Ogbeifun, D. E., \& Okieimen, F. E. (2011). Polymer applications in agriculture. Biokemistri, 23(2)

6. Roy, A., Singh, S. K., Bajpai, J., \& Bajpai, A. K. (2014). Controlled pesticide release from biodegradable polymers. Central European Journal of Chemistry, 12(4), 453-469. http:// dx.doi.org/10.2478/s11532-013-0405-2.

7. Woodhouse, J., \& Johnson, M. S. (1991). Effect of superabsorbent polymers on survival and growth of crop seedlings. Agricultural Water Management, 20(1), 63-70. http://dx.doi.org/10.1016/03783774(91)90035-H.

8. Sharma, S., Dua, A., \& Malik, A. (2014). Polyaspartic acid based superabsorbent polymers. European Polymer Journal, 59 , 363-376. http://dx.doi.org/10.1016/j.eurpolymj.2014.07.043.
9. Reetz, H. F., Jr. (2016). Fertilizers and their efficient use. Paris: IFA.

10. Trenkel, M. E. (2010). Slow- and controlled-release and stabilized fertilizers: an option for enhancing nutrient use efficiency in agriculture. Paris: IFA.

11. Pereira, E. I., Giroto, A. S., Bortolin, A., Yamamoto, C. F., Marconcini, J. M., de Campos Bernardi, A. C., \& Ribeiro, C. (2015). Perspectives in nanocomposites for the slow and controlledrelease of agrochemicals: fertilizers and pesticides. In M. Rai, C. Ribeiro, L. Mattoso, \& N. Duran (Eds.), Nanotechnologies in food and agriculture (pp. 241-265). Minneapolis: Springer. http://dx.doi.org/10.1007/978-3-319-14024-7_11.

12. Shaviv, A. (2001). Advances in controlled-release fertilizers. Advances in Agronomy, 71, 1-49. http://dx.doi.org/10.1016/ S0065-2113(01)71011-5.

13. Trenkel, M. E. (1997). Controlled-release and stabilized fertilizers in agriculture (Vol. 11). Paris: International Fertilizer Industry Association.

14. Noppakundilograt, S., Pheatcharat, N., \& Kiatkamjornwong, S. (2015). Multilayer coated NPK compound fertilizer hydrogel with controlled nutrient release and water absorbency. Journal of Applied Polymer Science, 132(2) http://dx.doi.org/10.1002/ app.41249.

15. Du, C. W., Zhou, J. M., \& Shaviv, A. (2006). Release characteristics of nutrients from polymer-coated compound controlled-release fertilizers. Journal of Polymers and the Environment, 14(3), 223-230. http://dx.doi.org/10.1007/s10924-006-0025-4.

16. Melaj, M. A., \& Daraio, M. E. (2013). Preparation and characterization of potassium nitrate controlled release fertilizers based on chitosan and xanthan layered tablets. Journal of Applied Polymer Science, 130(4), 2422-2428. http://dx.doi. org/10.1002/app.39452.

17. Oertli, J. J., \& Lunt, O. R. (1962). Controlled-release of fertilizer minerals by incapsulating membranes: I. Factors influencing the rate of release. Soil Science Society of America Journal, 26(6), 579-583. http://dx.doi.org/10.2136/sssaj1962.036159 95002600060019x.

18. Al-Zahrani, S. M. (1999). Controlled-release of fertilizers: modelling and simulation. International Journal of Engineering Science, 37(10), 1299-1307. http://dx.doi.org/10.1016/S00207225(98)00120-7.

19. Allan, G. G., Chopra, C. S., Neogi, A. N., \& Wilkins, R. M. (1971). Design and synthesis of controlled-release pesticide-polymer combinations. Nature, 234(5328), 349-351. PMid:4944486. http://dx.doi.org/10.1038/234349a0.

20. Lvov, Y. M., Shchukin, D. G., Mohwald, H., \& Price, R. R. (2008). Halloysite clay nanotubes for controlled-release of protective agents. ACS Nano, 2(5), 814-820. PMid:19206476. http://dx.doi.org/10.1021/nn800259q.

21. Qian, K., Shi, T., Tang, T., Zhang, S., Liu, X., \& Cao, Y. (2011). Preparation and characterization of nano-sized calcium carbonate as controlled-release pesticide carrier for validamycin against Rhizoctonia solani. Mikrochimica Acta, 173(1-2), 51-57. http:// dx.doi.org/10.1007/s00604-010-0523-x.

22. Pérez de Luque, A., \& Hermosín, M. C. (2013). Nanotechnology and its use in agriculture. In D. Bagchi (Ed.), Bio-nanotechnology: a revolution in food, biomedical and health sciences (pp. 383-398). Oxford: Blackwell Publishing Ltd. http://dx.doi. org/10.1002/9781118451915.ch20.

23. Kashyap, P. L., Xiang, X., \& Heiden, P. (2015). Chitosan nanoparticle based delivery systems for sustainable agriculture. International Journal of Biological Macromolecules, 77, 36-51. PMid:25748851. http://dx.doi.org/10.1016/j.ijbiomac.2015.02.039.

24. Ibrahim, S., Nawwar, G. A., \& Sultan, M. (2016). Development of bio-based polymeric hydrogel: green, sustainable and low cost plant fertilizer packaging material. Journal of 
Environmental Chemical Engineering, 4(1), 203-210. http:// dx.doi.org/10.1016/j.jece.2015.10.028.

25. Hussain, M. R., Devi, R. R., \& Maji, T. K. (2012). Controlledrelease of urea chitosan microspheres prepared by emulsification and cross - linking method. Iranian Polymer Journal, 21(8), 473-479. http://dx.doi.org/10.1007/s13726-012-0051-0.

26. Costa, M. M. E., Cabral-Albuquerque, E. C. M., Alves, T. L., Pinto, M. J. C., \& Fialho, R. L. (2013). Use of polyhydroxybutyrate and ethyl cellulose for coating of urea granules. Journal of Agricultural and Food Chemistry, 61(42), 9984-9991. PMid:24059839. http://dx.doi.org/10.1021/jf401185y.

27. Azeem, B., KuShaari, K., Man, Z. B., Basit, A., \& Thanh, T. H. (2014). Review on materials \& methods to produce controlledrelease coated urea fertilizer. Journal of Controlled Release, 181, 11-21. PMid:24593892. http://dx.doi.org/10.1016/j. jconrel.2014.02.020.

28. Sabadini, R. C., Martins, V. C., \& Pawlicka, A. (2015). Synthesis and characterization of gellan gum: chitosan biohydrogels for soil humidity control and fertilizer release. Cellulose, 22(3), 2045-2054. http://dx.doi.org/10.1007/s10570-015-0590-6.

29. Noppakundilograt, S., Pheatcharat, N., \& Kiatkamjornwong, S. (2015). Multilayer coated NPK compound fertilizer hydrogel with controlled nutrient release and water absorbency. Journal of Applied Polymer Science, 132(2) http://dx.doi.org/10.1002/ app.41249.

30. Lubkowski, K., \& Grzmil, B. (2007). Controlled-release fertilizers. Polish Journal of Chemical Technology, 9(4), 8184. http://dx.doi.org/10.2478/v10026-007-0096-6.

31. Senna, A. M., Carmo, J. B., Silva, J. M. S., \& Botaro, V. R. (2015). Synthesis, characterization and application of hydrogel derived from cellulose acetate as a substrate for slowrelease NPK fertilizer and water retention in soil. Journal of Environmental Chemical Engineering, 3(2), 996-1002. http:// dx.doi.org/10.1016/j.jece.2015.03.008.

32. Ahmad, N. N. R., Fernando, W. J. N., \& Uzir, M. H. (2015). Parametric evaluation using mechanistic model for release rate of phosphate ions from chitosan-coated phosphorus fertiliser pellets. Biosystems Engineering, 129, 78-86. http://dx.doi. org/10.1016/j.biosystemseng.2014.09.015.

33. Melaj, M. A., \& Daraio, M. E. (2014). HPMC layered tablets modified with chitosan and xanthan as matrices for controlled $\square$ release fertilizers. Journal of Applied Polymer Science, 131(19), 40839. http://dx.doi.org/10.1002/app.40839.

34. Santos, B. R., Bacalhau, F. B., Pereira, T. S., Souza, C. F., \& Faez, R. (2015). Chitosan-montmorillonite microspheres: a sustainable fertilizer delivery system. Carbohydrate Polymers, 127, 340-346. PMid:25965492. http://dx.doi.org/10.1016/j. carbpol.2015.03.064.

35. Messa, L. L., Froes, J. D., Souza, C. F., \& Faez, R. (2016). Híbridos de quitosana-argila para encapsulamento e liberação sustentada do fertilizante nitrato de potássio. Quimica Nova, 39(10), 1215-1220. http://dx.doi.org/10.21577/01004042.20160133 .

36. Grillo, R., Clemente, Z., Oliveira, J. L., Campos, E. V. R., Chalupe, V. C., Jonsson, C. M., Lima, R., Sanches, G., Nishisaka, C. S., Rosa, A. H., Oehlke, K., Greiner, R., \& Fraceto, L. F. (2015). Chitosan nanoparticles loaded the herbicide paraquat: the influence of the aquatic humic substances on the colloidal stability and toxicity. Journal of Hazardous Materials, 286, 562-572. PMid:25636059. http://dx.doi.org/10.1016/j. jhazmat.2014.12.021.

37. Celis, R., Adelino, M. A., Hermosín, M. C., \& Cornejo, J. (2012). Montmorillonite-chitosan bionanocomposites as adsorbents of the herbicide clopyralid in aqueous solution and soil/water suspensions. Journal of Hazardous Materials,
209-210, 67-76. PMid:22284171. http://dx.doi.org/10.1016/j. jhazmat.2011.12.074.

38. Liu, F., Wen, L. X., Li, Z. Z., Yu, W., Sun, H. Y., \& Chen, J. F. (2006). Porous hollow silica nanoparticles as controlled delivery system for water-soluble pesticide. Materials Research Bulletin, 41(12), 2268-2275. http://dx.doi.org/10.1016/j. materresbull.2006.04.014.

39. Azeem, B., KuShaari, K., Man, Z. B., Basit, A., \& Thanh, T. H. (2014). Review on materials \& methods to produce controlledrelease coated urea fertilizer. Journal of Controlled Release, 181, 11-21. PMid:24593892. http://dx.doi.org/10.1016/j. jconrel.2014.02.020.

40. Davidson, D., \& Gu, F. X. (2012). Materials for sustained and controlled-release of nutrients and molecules to support plant growth. Journal of Agricultural and Food Chemistry, 60(4), 870-876. PMid:22224363. http://dx.doi.org/10.1021/ jf204092h.

41. Akiyama, H., Yan, X., \& Yagi, K. (2010). Evaluation of effectiveness of enhanced efficiency fertilizers as mitigation options for $\mathrm{N} 2 \mathrm{O}$ and $\mathrm{NO}$ emissions from agricultural soils: meta analysis. Global Change Biology, 16(6), 1837-1846. http://dx.doi.org/10.1111/j.1365-2486.2009.02031.x.

42. Dubey, S., Jhelum, V., \& Patanjali, P. K. (2011). Controlledrelease agrochemicals formulations: a review. Journal of Scientific and Industrial Research, 70(2), 105-112.

43. Ghormade, V., Deshpande, M. V., \& Paknikar, K. M. (2011). Perspectives for nano-biotechnology enabled protection and nutrition of plants. Biotechnology Advances, 29(6), 792-803. PMid:21729746. http://dx.doi.org/10.1016/j.biotechadv.2011.06.007.

44. Shavit, U., Shaviv, A., Shalit, G., \& Zaslavsky, D. (1997). Release characteristics of a new controlled-release fertilizer. Journal of Controlled Release, 43(2), 131-138. http://dx.doi. org/10.1016/S0168-3659(96)01478-2.

45. Shavit, U., Reiss, M., \& Shaviv, A. (2003). Wetting mechanisms of gel-based controlled-release fertilizers. Journal of Controlled Release, 88(1), 71-83. PMid:12586505. http://dx.doi.org/10.1016/ S0168-3659(02)00455-8.

46. Lu, S. M., \& Lee, S. F. (1992). Slow release of urea through latex film. Journal of Controlled Release, 18(2), 171-180. http://dx.doi.org/10.1016/0168-3659(92)90187-V.

47. Buwalda, S. J., Boere, K. W., Dijkstra, P. J., Feijen, J., Vermonden, T., \& Hennink, W. E. (2014). Hydrogels in a historical perspective: From simple networks to smart materials. Journal of Controlled Release, 190, 254-273. PMid:24746623. http://dx.doi.org/10.1016/j.jconrel.2014.03.052.

48. Künzler, J. F. (1996). Silicone hydrogels for contact lens application. Trends in Polymer Science, 2(4), 52-59.

49. Nicolson, P. C., \& Vogt, J. (2001). Soft contact lens polymers: an evolution. Biomaterials, 22(24), 3273-3283. PMid:11700799. http://dx.doi.org/10.1016/S0142-9612(01)00165-X.

50. Kopeček, J. (2009). Hydrogels: From soft contact lenses and implants to self assembled nanomaterials. Journal of Polymer Science. Part A, Polymer Chemistry, 47(22), 5929-5946. PMid:19918374. http://dx.doi.org/10.1002/pola.23607.

51. Kellenberger, S. R. (1992). US Patent No. 5.147.343. Washington: U.S. Patent and Trademark Office.

52. Kozak, T. F. (1975). US Patent No. 3.890.974. Washington: U.S. Patent and Trademark Office.

53. Peppas, N. A. (1997). Hydrogels and drug delivery. Current Opinion in Colloid \& Interface Science, 2(5), 531-537. http:// dx.doi.org/10.1016/S1359-0294(97)80103-3.

54. Peppas, N. A., Keys, K. B., Torres-Lugo, M., \& Lowman, A. M. (1999). Poly (ethylene glycol)-containing hydrogels in drug delivery. Journal of Controlled Release, 62(1-2), 
81-87. PMid:10518639. http://dx.doi.org/10.1016/S01683659(99)00027-9.

55. Kamath, K. R., \& Park, K. (1993). Biodegradable hydrogels in drug delivery. Advanced Drug Delivery Reviews, 11(1), 59-84. http://dx.doi.org/10.1016/0169-409X(93)90027-2.

56. Zohuriaan-Mehr, M. J., Omidian, H., Doroudiani, S., \& Kabiri, K. (2010). Advances in non-hygienic applications of superabsorbent hydrogel materials. Journal of Materials Science, 45(21), 5711-5735. http://dx.doi.org/10.1007/s10853010-4780-1.

57. Erickson, R. E. (1984). US Patent No. 4.424.247. Washington: U.S. Patent and Trademark Office.

58. Redenbaugh, M. K. (1988). US Patent No. 4.779.376. Washington: U.S. Patent and Trademark Office.

59. Ullah, F., Othman, M. B., Javed, F., Ahmad, Z., \& Md Akil, H. (2015). Classification, processing and application of hydrogels: a review. Materials Science and Engineering C, 57, 414-433. PMid:26354282. http://dx.doi.org/10.1016/j.msec.2015.07.053.

60. Zohuriaan-Mehr, M. J., Omidian, H., Doroudiani, S., \& Kabiri, K. (2010). Advances in non-hygienic applications of superabsorbent hydrogel materials. Journal of Materials Science, 45(21), 5711-5735. http://dx.doi.org/10.1007/s10853010-4780-1.

61. Samchenko, Y., Ulberg, Z., \& Korotych, O. (2011). Multipurpose smart hydrogel systems. Advances in Colloid and Interface Science, 168(1-2), 247-262. PMid:21782148. http://dx.doi. org/10.1016/j.cis.2011.06.005.

62. Callaghan, T. V., Abdelnour, H., \& Lindley, D. K. (1988). The environmental crisis in the Sudan: the effect of water-absorbing synthetic polymers on tree germination and early survival. Journal of Arid Environments, 14(3), 301-317.

63. Woodhouse, J., \& Johnson, M. S. (1991). Effect of superabsorbent polymers on survival and growth of crop seedlings. Agricultural Water Management, 20(1), 63-70. http://dx.doi.org/10.1016/03783774(91)90035-H.

64. Stahl, J. D., Cameron, M. D., Haselbach, J., \& Aust, S. D. (2000). Biodegradation of superabsorbent polymers in soil. Environmental Science and Pollution Research International, 7(2), 83-88. PMid:19009427. http://dx.doi.org/10.1065/ espr199912.014.

65. Sutherland, G. R., Haselbach, J., \& Aust, S. D. (1997). Biodegradation of crosslinked acrylic polymers by a whiterot fungus. Environmental Science and Pollution Research International, 4(1), 16-20. PMid:19002412. http://dx.doi. org/10.1007/BF02986258.

66. Islam, M. R., Xue, X., Mao, S., Ren, C., Eneji, A. E., \& Hu, Y. (2011). Effects of water saving superabsorbent polymer on antioxidant enzyme activities and lipid peroxidation in oat (Avena sativa L.) under drought stress. Journal of the Science of Food and Agriculture, 91(4), 680-686. PMid:21302322. http://dx.doi.org/10.1002/jsfa.4234.

67. Sharma, S., Dua, A., \& Malik, A. (2014). Polyaspartic acid based superabsorbent polymers. European Polymer Journal, 59 , 363-376. http://dx.doi.org/10.1016/j.eurpolymj.2014.07.043.

68. Cannazza, G., Cataldo, A., De Benedetto, E., Demitri, C., Madaghiele, M., \& Sannino, A. (2014). Experimental assessment of the use of a novel superabsorbent polymer (SAP) for the optimization of water consumption in agricultural irrigation process. Water, 6(7), 2056-2069. http://dx.doi.org/10.3390/ w6072056.

69. Dragan, E. S. (2014). Design and applications of interpenetrating polymer network hydrogels. A review. Chemical Engineering Journal, 243, 572-590. http://dx.doi.org/10.1016/j.cej.2014.01.065.

70. Chauhan, G. S., \& Mahajan, S. (2002). Use of novel hydrogels based on modified cellulose and methacrylamide for separation of metal ions from water systems. Journal of Applied Polymer Science, 86(3), 667-671. http://dx.doi.org/10.1002/app.10943.

71. Zhan, F., Liu, M., Guo, M., \& Wu, L. (2004). Preparation of superabsorbent polymer with slow release phosphate fertilizer. Journal of Applied Polymer Science, 92(5), 3417-3421. http:// dx.doi.org/10.1002/app.20361.

72. Liang, R., Liu, M., \& Wu, L. (2007). Controlled-release NPK compound fertilizer with the function of water retention. Reactive \& Functional Polymers, 67(9), 769-779. http://dx.doi. org/10.1016/j.reactfunctpolym.2006.12.007.

73. Jamnongkan, T., \& Kaewpirom, S. (2010). Potassium release kinetics and water retention of controlled-release fertilizers based on chitosan hydrogels. Journal of Polymers and the Environment, 18(3), 413-421. http://dx.doi.org/10.1007/ s10924-010-0228-6.

74. Wang, J., \& Chen, C. (2009). Biosorbents for heavy metals removal and their future. Biotechnology Advances, 27(2), 195-226. PMid:19103274. http://dx.doi.org/10.1016/j. biotechadv.2008.11.002.

75. Campos, M. C. C. (2010). Atributos dos solos e riscos de lixiviação de metais pesados em solos tropicais. Ambiência, 6(3), 547-565. Retrieved in 11 September 2016, from http:// revistas.unicentro.br/index.php/ambiencia/article/view/591/1154

76. Gonçalves, A. C., Jr., Luchese, E. B., \& Lenzi, E. (2000). Avaliação da fitodisponibilidade de cádmio, chumbo e crômio, em soja cultivada em Latossolo Vermelho escuro tratado com fertilizantes comerciais. Quimica Nova, 23(2), 173-177. http:// dx.doi.org/10.1590/S0100-40422000000200006.

77. Aguiar, M. R. M. P., Novaes, A. C., \& Guarino, A. W. S. (2002). Remoção de metais pesados de efluentes industriais por aluminossilicatos. Química Nova, 25(6/B), 1145-1154. Retrieved in 18 October 2016, from http://quimicanova.sbq. org.br/detalhe artigo.asp?id $=5391$

78. Zhiming, Z., Zhanbin, H., Ke, T., \& Entong, L. (2013, August). The leaching research of environmental materials on $\mathrm{Pb}$ and $\mathrm{Cd}$ contaminated soil. In Proceedings of the 2013 the International Conference on Remote Sensing, Environment and Transportation Engineering (RSETE 2013) (pp. 493- 496). Nanjing, China: Atlantis Press.

79. Steffen, G. P. K., Steffen, R. B., \& Antoniolli, Z. I. (2011). Contaminação do solo e da água pelo uso de agrotóxicos. Tecnologica, 15(1), 15-21. http://dx.doi.org/10.17058/tecnolog. v15i1.2016.

80. Rangabhashiyam, S., Anu, N., Giri Nandagopal, M. S., \& Selvaraju, N. (2014). Relevance of isotherm models in biosorption of pollutants by agricultural byproducts. Journal of Environmental Chemical Engineering, 2(1), 398-414. http:// dx.doi.org/10.1016/j.jece.2014.01.014.

81. Airoldi, C. (2008). A relevante potencialidade dos centros básicos nitrogenados disponíveis em polímeros inorgânicos e biopolímeros na remoção catiônica. Quimica Nova, 31(1), 144-153. http://dx.doi.org/10.1590/S0100-40422008000100026.

82. Demirbas, A. (2008). Heavy metal adsorption onto agro-based waste materials: a review. Journal of Hazardous Materials, 157(2-3), 220-229. PMid:18291580. http://dx.doi.org/10.1016/j. jhazmat.2008.01.024.

83. Wan Ngah, W. S., Teong, L. C., \& Hanafiah, M. A. K. M. (2011). Adsorption of dyes and heavy metal ions by chitosan composites: a review. Carbohydrate Polymers, 83(4), 14461456. http://dx.doi.org/10.1016/j.carbpol.2010.11.004.

84. Davis, T. A., Volesky, B., \& Mucci, A. (2003). A review of the biochemistry of heavy metal biosorption by brown algae. Water Research, 37(18), 4311-4330. http://dx.doi.org/10.1016/ S0043-1354(03)00293-8.

85. Pitol-Filho, L. (2011). Aplicações sustentáveis de biomassa: novas perspectivas. Revista da UNIFEBE, l(9), 100-109. 
Retrieved in 25 September 2016, from http://periodicos. unifebe.edu.br/index.php/revistael etronicadaunifebe/article/ view/64/53

86. Kavamura, V. N., \& Esposito, E. (2010). Biotechnological strategies applied to the decontamination of soils polluted with heavy metals. Biotechnology Advances, 28(1), 61-69. PMid:19778598. http://dx.doi.org/10.1016/j.biotechadv.2009.09.002.

87. Pal, A., \& Paul, A. K. (2008). Microbial extracellular polymeric substances: central elements in heavy metal bioremediation. Indian Journal of Microbiology, 48(1), 49-64. PMid:23100700. http://dx.doi.org/10.1007/s12088-008-0006-5.

88. Ferreira, P. P. L., Braga, R. M., Teodoro, N. M. A., Melo, V. R. M., Melo, D. M. A., \& Melo, M. A. F. (2015). Adsorção de $\mathrm{Cu} 2+$ e $\mathrm{Cr} 3+$ em efluentes líquidos utilizando a cinza do bagaço da cana-de-açúcar. Cerâmica, 61(360), 435-441. http:// dx.doi.org/10.1590/0366-69132015613601945.

89. Zolgharnein, J., Asanjarani, N., \& Shariatmanesh, T. (2011). Removal of thallium(I) from aqueous solution using modified sugar beet pulp. Toxicological and Environmental Chemistry, 93(2), 207-214. http://dx.doi.org/10.1080/02772248.2010.52 3424.

90. Kumar, S., \& Meikap, B. C. (2014). Removal of chromium (VI) from waste water by using adsorbent prepared from green coconut shell. Desalination and Water Treatment, 52(16-18), 3122-3132. http://dx.doi.org/10.1080/19443994.2013.80179 6.

91. Tao, Y., Ye, L., Pan, J., Wang, Y., \& Tang, B. (2009). Removal of $\mathrm{Pb}$ (II) from aqueous solution on chitosan/TiO 2 hybrid film. Journal of Hazardous Materials, 161(2-3), 718-722. PMid:18495341.http://dx.doi.org/10.1016/j.jhazmat.2008.04.012.

92. Lim, J., Kang, H. M., Kim, L. H., \& Ko, S. O. (2008). Removal of heavy metals by sawdust adsorption: equilibrium and kinetic studies. Environmental Engineering Research, 13(2), 79-84. Retrieved in 20 September 2016, from http://eeer.org/upload/ eer-13-2-79-.pdf

93. Dal Magro, C., Deon, M. C., Thomé, A., Piccin, J. S., \& Colla, L. M. (2013). Biossorção passiva de cromo (VI) através da microalga Spirulina platensis. Quimica Nova, 36(8), 1139-1145. http://dx.doi.org/10.1590/S0100-40422013000800011.

94. Sobhanardakani, S., Parvizimosaed, H., \& Olyaie, E. (2013). Heavy metals removal from wastewaters using organic solid waste-rice husk. Environmental Science and Pollution Research International, 20(8), 5265-5271. PMid:23381799. http://dx.doi.org/10.1007/s11356-013-1516-1.

95. Anwar, J., Shafique, U., Waheed-uz-Zaman, Salman, M., Dar, A., \& Anwar, S. (2010). Removal of Pb (II) and Cd (II) from water by adsorption on peels of banana. Bioresource Technology, 101(6), 1752-1755. PMid:19906528. http://dx.doi. org/10.1016/j.biortech.2009.10.021.

96. Paulino, Á. G., Cunha, A. J., Alfaya, R. V. S., \& Alfaya, A. A. S. (2014). Chemically modified natural cotton fiber: a low-cost biosorbent for the removal of the $\mathrm{Cu}(\mathrm{II}), \mathrm{Zn}(\mathrm{II}), \mathrm{Cd}(\mathrm{II})$, and $\mathrm{Pb}$ (II) from natural water. Desalination and Water Treatment, 52(22-24), 4223-4233. http://dx.doi.org/10.1080/19443994.2 013.804451 .
97. Barka, N., Abdennouri, M., Boussaoud, A., \& EL Makhfouk, M. (2010). Biosorption characteristics of Cadmium (II) onto Scolymus hispanicus L. as low-cost natural biosorbent. Desalination, 258(1), 66-71. http://dx.doi.org/10.1016/j. desal.2010.03.046.

98. Mahmoud, M. E., Yakout, A. A., Abdel-Aal, H., \& Osman, M. M. (2013). Immobilization of Fusarium verticillioides fungus on nano-silica (NSi-Fus): A novel and efficient biosorbent for water treatment and solid phase extraction of $\mathrm{Mg}$ (II) and $\mathrm{Ca}$ (II). Bioresource Technology, 134, 324-330. PMid:23517902. http://dx.doi.org/10.1016/j.biortech.2013.01.171.

99. Lucas, N., Bienaime, C., Belloy, C., Queneudec, M., Silvestre, F., \& Nava-Saucedo, J. E. (2008). Polymer biodegradation: mechanisms and estimation techniques. Chemosphere, 73(4), 429-442. PMid:18723204. http://dx.doi.org/10.1016/j. chemosphere.2008.06.064.

100. Watanabe, T., Ohtake, Y., Asabe, H., Murakami, N., \& Furukawa, M. (2009). Biodegradability and degrading microbes of low density polyethylene. Journal of Applied Polymer Science, 111(1), 551-559. http://dx.doi.org/10.1002/app.29102.

101. Ge, J., Wu, R., Shi, X., Yu, H., Wang, M, \& Li, W. (2002). Biodegradable polyurethane materials from bark and starch. II. Coating material for controlled release fertilizer. Journal of Applied Polymer Science, 86(12), 2948-2952. http://dx.doi. org/10.1002/app.11211.

102. Shah, A. A., Hasan, F., Hameed, A., \& Ahmed, S. (2008). Biological degradation of plastics: a comprehensive review. Biotechnology Advances, 26(3), 246-265. PMid:18337047. http://dx.doi.org/10.1016/j.biotechadv.2007.12.005.

103. Roseman, T. J. (1972). Release of steroids from a silicone polymer. Journal of Pharmaceutical Sciences, 61(1), 46-50. PMid:5058644. http://dx.doi.org/10.1002/jps.2600610106.

104. Ritger, P. L., \& Peppas, N. A. (1987). A simple equation for description of solute release I. Fickian and non-Fickian release from non-swellable devices in the form of slabs, spheres, cylinders or discs. Journal of Controlled Release, 5(1), 23-36. http://dx.doi.org/10.1016/0168-3659(87)90034-4.

105. Saruchi, K., Kaith, B. S., Jindal, R., \& Kumar, V. (2015). Biodegradation of Gum tragacanth acrylic acid based hydrogel and its impact on soil fertility. Polymer Degradation \& Stability, 115, 24-31. http://dx.doi.org/10.1016/j. polymdegradstab.2015.02.009.

106. Ye, H., Zhao, J. Q. \& Zhang, Y. H., (2004). Novel degradable superabsorbent materials of silicate/acrylic based polymer hybrids. Journal of Applied Polymer Science, 91(2), 936-940. http://dx.doi.org/10.1002/app.13274.

107. Wilske, B., Bai, M., Lindenstruth, B., Bach, M., Rezaie, Z., Frede, H. G., \& Breuer, L. (2014). Biodegradability of a polyacrylate superabsorbent in agricultural soil. Environmental Science and Pollution Research International, 21(16), 94539460. PMid:24037296. http://dx.doi.org/10.1007/s11356013-2103-1.

Received: July 15, 2016 Revised: Nov. 19, 2016 Accepted: Mar. 01, 2017 